\title{
The role of e-engagement and flow on the continuance with a learning management system in a blended learning environment
}

\author{
Tiong-Thye Goh ${ }^{1}$ and Bing Yang ${ }^{2^{*}}$ (D)
}

\author{
${ }^{*}$ Correspondence: \\ yangbing.cn88@gmail.com \\ ${ }^{2}$ School of Education, Hubei \\ University, 368 Youyi Avenue, \\ Wuchang, Wuhan, Hubei, \\ China \\ Full list of author information \\ is available at the end of the \\ article
}

\begin{abstract}
E-learning systems are widely deployed in higher education institutions but sustaining students' continued use of e-learning systems remains challenging. This study investigated the relationship between e-learning engagement, flow experience and learning management system continuance via a mediated moderation interaction model. The context of the study is a Moodle LMS supporting a blended learning environment. After controlling age and gender, a PLS analysis of 92 students' samples with a reflective flow construct explained $49 \%$ of the variance in the research model. The analysis shows that flow mediates e-engagement and perceived ease of use with a direct positive impact on e-learning system continuance. Flow has an indirect impact through perceived usefulness on e-learning system continuance. However, the direct impact of flow on system continuance weakens as e-learning engagement increases. This finding may help to explain the mixed and inconsistent impact of flow in the e-learning system continuance literature. The dual effect of flow suggests that instructors must carefully balance pedagogical decisions intended to heighten flow experience to generate positive learning outcomes through e-engagement and its consequence of reduced impact on continued system use.
\end{abstract}

Keywords: Flow, Learning management system continuance, e-Learning engagement

\section{Introduction}

Learning management systems (LMS) provide an important delivery channel that overcomes the constraints of space and time in traditional face-to-face learning (Schophuizen et al., 2018; Zhao et al., 2020). Currently, there are many learning management systems, for example, WebCT, Moodle, OLAT, and Sakai. Despite their technological and pedagogical affordances, sustaining students' continuous use of LMS remains challenging in both the online and blended learning environment (Ashrafi et al., 2020; Choudhury \& Pattnaik, 2020; Rasheed et al., 2020). According to Rasheed et al. (2020) there is a gap in understanding of the online component of blended learning and the 
issues facing students that prevent the continued use of LMS. Rasheed et al. (2020) and Ashrafi et al. (2020) in their studies identified technological literacy, competency and complexity, system navigation and hedonic factors among other factors that are challenging students' use of LMS in blended learning. These factors directly affect students' intrinsic and extrinsic motivation and their perceived intention of using the LMS. Ashrafi et al. (2020) concur in their study and believe it is of immense importance to understanding the underlying mechanisms that encourage learners to continue use of learning management systems beyond system adoption and usage. The technology acceptance model (TAM) which focused on the utilitarian perspective has been widely applied to investigate learners' acceptance and continued use of e-learning systems (Granić \& Marangunić, 2019; Scherer \& Teo, 2019). Factors such as perceived usefulness, ease of use, and students' attitudes toward technology have been found to be key influencing factors. However, recent advancement of e-learning technologies applications such as educational games, virtual reality, interactive classroom responses, group chat, real-time interactive video and analytics highlighted the rapid development of LMS pedagogical functionalities. With such a rapid development, there is a need to identify new factors and moderators that could better explain the dynamic nature of students' motivation and continued system use. Moreover, as part of the learning management systems modules these learning applications require students to consistently use and engage with them to achieve the learning objectives. These new applications within LMS will generate new forms of interaction and usage dynamics that require understanding but have currently received limited attention in research (Granić \& Marangunić, 2019; ŠUmak et al., 2011; Sun \& Zhang, 2006).

To understand the dynamic nature of students' motivation and continued system use, we propose a model that integrates the technology acceptance model and the flow experience (Csikszentmihalyi, 1975) that is derived from engaging with various learning activities of e-learning systems. Csikszentmihalyi (1975) introduced the theory of flow in the 1970s. Flow is described as the optimal engaging experience characterised by intense focus, control, interest and a balance of skill and challenges. Flow experience makes learners feel fully immersed in their learning engagement and influences their subsequent usage behaviour. It is a cohesive construct useful for designing, evaluating and explaining human-technology interaction and continued usage experience (Oliveira, 2019). Unlike the utilitarian perspective of TAM, flow experience is associated with motivational drive and is perceived to be a universal experience that occurs across all classes, genders, ages, and cultures while engaging with different activities (Mihaly Csikszentmihalyi \& Asakawa, 2016). Moreover, flow experience is linked to individual intrinsic motivations that could complement the extrinsic motivations of the TAM model (Cheng, 2013; Nakamura et al., 2019). By integrating flow into the TAM model and including the interaction of individual factors, the model contains dual motivation factors that could better explain the dynamic nature of students' motivation and continued system use.

The rest of the paper is organised as follows. In the next section, we discuss related research based on e-learning systems that utilise flow theory. Then, we explain the research model and develop the hypotheses. Next, we discuss the research methodology which includes the measurement instrument, data collection and data analysis. Lastly, a 
discussion, implications for future research, limitations and a conclusion complete the paper.

\section{Related work}

Flow Theory has been utilised to address the issues of students' learning motivation, engagement, exploration, satisfaction, and performance in various application domains, notably in e-learning, educational games, virtual worlds and virtual learning environments (Auld, 2014; dos Santos et al., 2018). Despite its popularity, research findings on the relationship between flow experience and students' continued usage intention towards e-learning systems remain limited and dominated by inconsistency. Table 1 provides a spectrum of studies from 2005 to 2020 comprising flow experience as an independent variable and continued usage intention as a dependent variable. A few observations can be made.

First, the flow and continued usage intention relationship is inconsistent. For instance, a study by Davis and Wong (2007) showed that flow experience has a direct impact on the intention to use an e-learning system and it was a stronger predictor than the perceived usefulness. It demonstrated that the affective flow state is more important in determining a learner's intention to use an e-learning system than the learner's beliefs about the usefulness of an e-learning system. However, the finding by Rodríguez-Ardura and Meseguer-Artola (2016) showed that flow experience and perceived usefulness were mediated by attitude, with flow having a very small indirect influence on continuance intention compared to perceived usefulness. Yet Guo et al. (2016) showed that flow experience had no direct impact but an indirect impact on continuance intention to use online courses. Table 1 also quantifies the impact of flow on continued usage intention, which varies from no impact to a high direct impact of 0.61 with a median value of 0.17 . All the studies except the one by Khan et al., (2017) did not consider control variables and moderators. The model fit measured by $\mathrm{R}^{2}$ varies from 0.275 to 0.581 with a median of 0.37. These inconsistent relationships suggest that the flow dynamic is complex and sensitive to unknown situational and individual factors that were not considered in the studies (Mahnke et al., 2014; Sun \& Zhang, 2006).

Second, the flow construct is inconsistent. Operationalisations of the flow construct range from a simple first-order construct to a second-order construct. For instance, the study by Meyer and Jones (2013) adopted a single dimension 7-item scale to ascertain that concentration and focus, sense of control and a clear goal were correlated with course satisfaction in online courses. Guo et al. (2016), however, adopted a second order 4-dimension scale to show that telepresence, immersive experience and enjoyment are related to flow and generate a chain of positive outcomes when applied in an integrated flow framework model. Zhao et al. (2020), on the other hand, adopted a single dimension 3-item scale to ascertain that telepresence and social presence are predictors of flow related to the intention to continue using MOOCs.

Lastly, most studies on the relationship between flow and continued system use treat flow as an "optimal experience" associated with a broad variety of positive outcomes in terms of positive motivation, well-being and performance (Zimanyi \& Schüler, 2021). There was little discussion on whether the impact of flow would be weakened or inverted due to factors associated with the intensity and the types of interaction activities within 
Table 1 A survey of flow constructs and its impact measured by path strength and $R^{2}$ on continued intention in e-learning

\begin{tabular}{|c|c|c|c|c|c|}
\hline References & Constructs & Dependents & Flow Impact & $\mathrm{R}^{2}$ & Flow Construct \\
\hline Cheng (2013) & $\begin{array}{l}\text { Perceived useful- } \\
\text { ness } \\
\text { Perceived ease } \\
\text { of use } \\
\text { Flow }\end{array}$ & $\begin{array}{l}\text { Intention to use } \\
\text { e-learning } \\
\text { systems }\end{array}$ & 0.146 & 0.917 (GFI) & $\begin{array}{l}1 \text { dimension ( } 3 \\
\text { items) } \\
\text { Absorption } \\
\text { Enjoyment } \\
\text { Passage of time }\end{array}$ \\
\hline Khan et al., (2017) & Flow Experience & $\begin{array}{l}\text { Use of learning } \\
\text { management } \\
\text { system }\end{array}$ & 0.184 & 0.333 & $\begin{array}{l}1 \text { dimension (4 } \\
\quad \text { items) } \\
\text { Fun } \\
\text { Interesting } \\
\text { Exciting } \\
\text { Absorbing }\end{array}$ \\
\hline $\begin{array}{l}\text { Saadé and Bahli } \\
\text { (2005) }\end{array}$ & $\begin{array}{l}\text { Cognitive absorp- } \\
\text { tion } \\
\text { Perceived useful- } \\
\text { ness } \\
\text { Perceived ease } \\
\text { of use }\end{array}$ & $\begin{array}{l}\text { Intention to use } \\
\text { online learning }\end{array}$ & $\begin{array}{l}0.17 \text { (competing } \\
\text { model) }\end{array}$ & 0.289 & $\begin{array}{l}2^{\text {nd }} \text { order (3 dimen- } \\
\text { sions) } \\
\text { Temporal dissocia- } \\
\text { tion } \\
\text { Focused immersion } \\
\text { Heightened enjoy- } \\
\text { ment }\end{array}$ \\
\hline $\begin{array}{l}\text { Esteban-Millat } \\
\text { et al., (2018) }\end{array}$ & $\begin{array}{l}\text { Perceived useful- } \\
\text { ness } \\
\text { Perceived ease } \\
\text { of use } \\
\text { Flow } \\
\text { Attitude }\end{array}$ & $\begin{array}{l}\text { Intention to use } \\
\text { an e-learning } \\
\text { environment }\end{array}$ & ns & $0.901(\mathrm{GFI})$ & $\begin{array}{l}1 \text { dimension ( } 3 \\
\text { items) } \\
\text { Experienced flow } \\
\text { Frequency of flow } \\
\text { Time on flow }\end{array}$ \\
\hline Hong et al., (2019) & $\begin{array}{l}\text { Prediction-obser- } \\
\text { vation-quiz- } \\
\text { explanation } \\
\text { Green energy } \\
\text { learning } \\
\text { Self-efficacy } \\
\text { Intrinsic cognitive } \\
\text { load } \\
\text { Incremental } \\
\text { belief of intel- } \\
\text { ligence } \\
\text { Flow }\end{array}$ & $\begin{array}{l}\text { Continuance } \\
\text { intention to use } \\
\text { e-learning for } \\
\text { green energy } \\
\text { learning }\end{array}$ & 0.525 & 0.275 & $\begin{array}{l}1 \text { dimension } \\
\text { (4 items) } \\
\text { Focus } \\
\text { Sense of time } \\
\text { Attention } \\
\text { Engrossment }\end{array}$ \\
\hline $\begin{array}{l}\text { Rodríguez-Ardura } \\
\text { and Meseguer- } \\
\text { Artola (2017) }\end{array}$ & $\begin{array}{l}\text { Challenge } \\
\text { Control } \\
\text { Focused atten- } \\
\quad \text { tion } \\
\text { Presence } \\
\text { Flow } \\
\text { Positive affect }\end{array}$ & Continuance & 0.01 (Indirect) & $0.928(\mathrm{GFI})$ & $\begin{array}{l}1 \text { dimension ( } 3 \\
\text { items) } \\
\text { Experienced flow } \\
\text { Frequency of flow } \\
\text { Time on flow }\end{array}$ \\
\hline Lu et al. (2019) & $\begin{array}{l}\text { Confirmation } \\
\text { Perceived useful- } \\
\text { ness } \\
\text { Perceived interest } \\
\text { Flow } \\
\text { Satisfaction }\end{array}$ & $\begin{array}{l}\text { Continuous } \\
\text { intention to use } \\
\text { MOOC }\end{array}$ & 0.142 (Indirect) & 0.438 & $\begin{array}{l}1 \text { dimension (3 } \\
\text { items) } \\
\text { Distraction } \\
\text { Frustration } \\
\text { Concentration }\end{array}$ \\
\hline Guo et al., (2016) & $\begin{array}{l}\text { Perceived } \\
\text { hedonic value } \\
\text { Perceived utilitar- } \\
\quad \text { ian value } \\
\text { Satisfaction } \\
\text { Flow }\end{array}$ & $\begin{array}{l}\text { Continuance } \\
\text { intention of } \\
\text { online learning }\end{array}$ & 0.524 (Indirect) & 0.52 & $\begin{array}{l}\text { 2nd order ( } 4 \text { dimen- } \\
\text { sions) } \\
\text { Concentration on } \\
\text { the task at hand } \\
\text { Loss of self-con- } \\
\text { sciousness } \\
\text { Sense of control } \\
\text { Time distortion }\end{array}$ \\
\hline
\end{tabular}


Table 1 (continued)

\begin{tabular}{|c|c|c|c|c|c|}
\hline References & Constructs & Dependents & Flow Impact & $R^{2}$ & Flow Construct \\
\hline Liu et al., (2009) & $\begin{array}{l}\text { Concentration } \\
\text { (flow) } \\
\text { Perceived ease } \\
\text { of use } \\
\text { Perceived useful- } \\
\text { ness } \\
\text { Attitude }\end{array}$ & Intentions & $\begin{array}{c}0.265 \text { (best } \\
\text { model) }\end{array}$ & 0.581 & $\begin{array}{l}1 \text { dimension (3 } \\
\text { items) } \\
\text { Absorption } \\
\text { Focus } \\
\text { Engrossment }\end{array}$ \\
\hline Zhao et al., (2020) & $\begin{array}{l}\text { Flow } \\
\text { Social presence } \\
\text { Telepresence }\end{array}$ & $\begin{array}{l}\text { Continuance } \\
\text { intention to use } \\
\text { MOOC system }\end{array}$ & 0.61 & 0.37 & $\begin{array}{l}1 \text { dimension ( } 3 \\
\text { items) } \\
\text { Absorption } \\
\text { Curiosity } \\
\text { Arousal }\end{array}$ \\
\hline
\end{tabular}

a learning management system context. According to Zimanyi and Schüler (2021), when individuals desire to experience flow over and over again it may generate addictive behaviour which concurs with Csikszentmihalyi's (1990, p. 62) flow theory that enjoyable activities that produce flow have a potentially negative aspect. Learning management systems' integration with gamification and social network activities may be prone to inducing negative effects. Hence, activities that induce flow experience by stimulating e-learning engagement may need to be aware of how flow would affect the overall learning and usage dynamic. To our knowledge, no study has investigated the role of flow in a mediated moderation model and how engagement affects the continued use of learning management systems in a blended environment.

\section{Research model and hypotheses}

According to Csikszentmihalyi (1975), when an individual experiences flow it is very enjoyable, and as a result, it will enhance task performance and lead to optimal performance. During the state of flow, one is "so focused that it amounts to absolute absorption in an activity." In the e-learning context, e-learning engagement allows students to focus, enjoy, concentrate and control, which induces flow experience, thus leading them to deep learning (Esteban-Millat et al., 2018) and consequently heightening their motivation to learn and retain the knowledge (Watted \& Barak, 2018).

Based on the synthesis of previous studies, we apply a multi-dimensional flow construct as an antecedent to the parsimonious TAM variables to obtain a better empirical solution (Guo et al., 2016; Siekpe, 2005). We include the moderating effect of e-learning engagement to quantify how flow relates to perceived usefulness, perceived ease of use and continuance intention to account for situational and individual factors (Gao et al., 2019; Sun \& Zhang, 2006). We apply the control variables of gender and age to strengthen the model's robustness (Cheng, 2013; Hsieh et al., 2016). The model is designed to verify the behaviour of flow experience and provides further insight into the dynamic of flow, how the impact of e-learning engagement heightens and moderates flow experience, and how flow experience has an impact on the continuance intention to use a learning management system. Figure 1 shows the mediated moderation conceptual model as described by Hayes (2017). In the model, flow experience has a direct impact on continued use intention and is moderated by e-learning engagement. Flow acts as a mediator on perceived ease of use. Flow and perceived ease of use have an indirect 


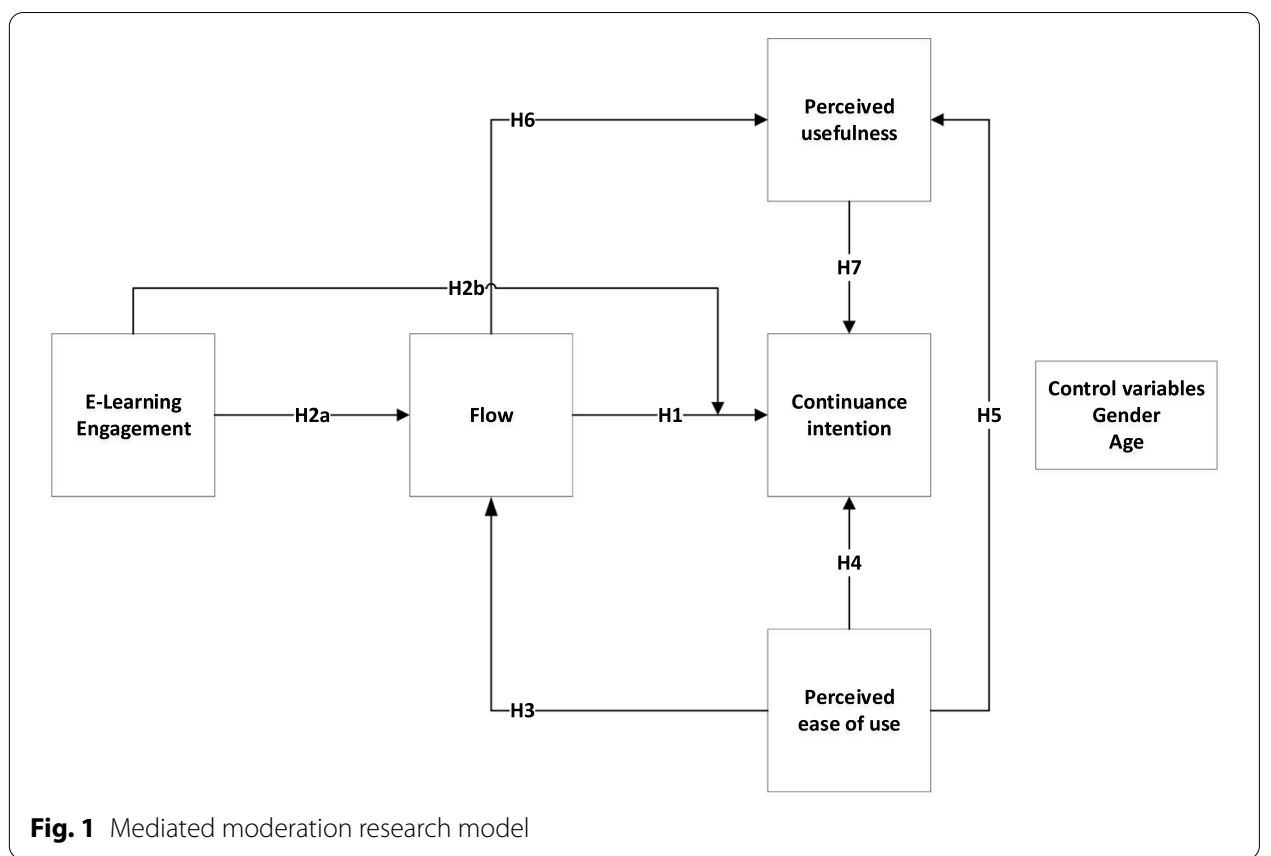

impact on continued use intention through perceived usefulness. Gender and age are the control variables. The flow experience is a reflective second-order construct which consists of the concentration, enjoyment, telepresence, and control dimensions.

\section{Flow and sense of control}

Flow refers to a state of optimal performance while engaged in motivating activities whereby individuals feel a sense of control over their behaviour and the situation without any fear of failure (van den Hout \& Davis, 2019). Choe et al. (2015) studied the obstacles to and facilitators of flow experience in e-learning. They used a purposive sampling method and semi-structured interviews with thematic and directed content analysis. Their results indicate that a sense of control is a major contributor to inducing flow and is related to the psychological condition of flow. Having a positive self-image, positive experiences, vision for the future, independent selection, confidence and team support promote the sense of control in building flow (van den Hout \& Davis, 2019).

\section{Flow and concentration}

Concentration refers to an individual being intensely absorbed with deeply focused attention and engrossed in the activity at hand (Ghani et al., 1991). Concentration is a significant component of flow. Flow experience is developed when a learner begins to concentrate on their activities (Koufaris, 2002; van den Hout \& Davis, 2019). Liu et al. (2009) studied content richness and flow concentration in an e-learning environment. Using a single concentration factor as the flow construct and TAM, they show that richer media were positively correlated with more concentration-oriented tasks. They confirm that high flow concentration levels positively influence learners' intention to use e-learning technology. Similarly, Lee (2010) and Lu et al. (2019) found that when 
students can concentrate on their learning activities, they tend to develop continuance intention to use e-learning technology.

\section{Flow and enjoyment}

Flow can be measured by the level of intrinsic enjoyment of an activity (Mahnke et al., 2014). Enjoyment means individuals experience activities as pleasurable, exciting, fun and interesting (Moon \& Kim, 2001). E-learning systems provide many opportunities to experience flow. Collaborative and learning activities such as chats, messages, discussion forums, videos and webinars may provide enjoyment to learners. Enjoyment as a dimension of flow affects learners' continued usage of e-learning (Lee, 2010; Muqtadiroh et al., 2019).

\section{Flow and telepresence}

During e-learning activities, when a student consciously experiences a sense of being physically present in a mediated world, the student is described as being in the state of telepresence (Weibel \& Wissmath, 2011). Telepresence is used to describe such intense experiences of being transported into another place, and not noticing the actual physical surroundings. Shin's (2006) study of online learners' 'flow' experience indicated that telepresence is part of the multidimensional construct of flow which has an impact on online learner satisfaction. Besides being a good predictor of online course satisfaction, students who were immersed in a high flow experience were more satisfied with the virtual e-learning environment. Zhao et al. (2020), in their study of the continuance of MOOC, showed that the technological-environmental features affect the experience of telepresence which subsequently affects flow experience.

In sum, when a learner is experiencing flow they are fully concentrating and enjoying the activities and are completely in control, thus motivating them to achieve better learning outcomes (Ho \& Kuo, 2010). A positive learning outcome is likely to motivate learners to continue using the e-learning system. Since flow experience appeared to have a positive relationship with the use of technology, a learner's flow experience will likely have a positive impact on the continuance intention to use e-learning systems (Scherer \& Teo, 2019). Hence, we posit that:

H1. Flow experience is positively related to the continuance intention to use the learning management systems.

\section{E-Learning engagement}

E-learning engagement is defined as the student's active involvement in activities designed as part of the learning via a learning management system to better acquire focal knowledge or skills (Hu \& Hui, 2012). We aggregate two items, usage intensity and learning activity, to measure e-learning engagement as an indicator for behavioural engagement (Schindler et al., 2017). Usage intensity is defined as the time users committed to activities within an e-learning system. Frequent use of a system increases familiarity and develops the skills to navigate the system. Familiarity and skill experience are conducive to developing flow experience. In a study of flow in computer-mediated interaction, frequency of medium use was positively related to flow experience (Liu et al., 2008). However, overuse can cause cognitive resistance to future use or attenuate attention 
to future use events, even though flow experience is elevated (Mahnke et al., 2014). Learning activity is defined as a mix of interaction between the subjects and the tools involved in the learning process. In the current context, the types of e-learning activities consist of reading PowerPoint slides, playing a game, having a virtual experience, taking quizzes and surveys, engaging in discussion and chat, and watching videos and webinars. According to Schindler et al. (2017), these computer-based learning activities represent a technology factor that affects students' engagement and directly relates to their flow experience (Sahid et al., 2016). For instance, goal-oriented processes are more conducive to developing flow than experiential types (Novak et al., 2003) and e-learning activities that challenge student abilities to reach new levels are conducive to triggering flow (Rodríguez-Ardura \& Meseguer-Artola, 2019). A learner who engages with more learning activities is more likely to encounter flow experiences. On the other hand, by engaging in more learning activities due to blended learning requirements, learners can get confused, fatigued, stressed or overloaded with activities that affect their intrinsic motivation and decrease their future use intention even though these learning activities heightened their flow experience (Zanjani, 2015). Thus, we posit that:

$\boldsymbol{H} 2 \boldsymbol{a}$. E-Learning engagement is positively related to flow experience.

$\boldsymbol{H} 2 \boldsymbol{b}$. E-Learning engagement negatively moderates the impact of flow experience on continuance intention to use the learning management system.

\section{Perceived ease of use}

Perceived ease of use is defined as "the degree to which a person believes that using a particular system would be free of physical and mental effort" (Davis, 1989, p. 320). TAM posits that perceived ease of use is a direct determinant of perceived usefulness and has a direct influence on behavioural intention (Eraslan Yalcin \& Kutlu, 2019). In e-learning systems, a difficult-to-use system can affect the perception of that system's usefulness and hinder the achievement of a flow state. According to Hsu and $\mathrm{Lu}$ (2004), if a user cannot overcome system difficulty, then the user may not appreciate the system's usefulness and may be unable to enjoy the flow experience. If a system is perceived as easy to handle, users will be more easily induced into higher immersion and concentration, which leads to the experience of flow (Matute-Vallejo \& Melero-Polo, 2019). Hence, we posit that:

H3. Perceived ease of use is positively related to flow experience.

H4. Perceived ease of use is positively related to continuance intention to use the learning management system.

H5. Perceived ease of use is positively related to perceived usefulness.

\section{Perceived usefulness}

The technology acceptance model (TAM) identifies that perceived usefulness and perceived ease of use are parsimonious determinants that affect users' behavioural intention. Perceived usefulness is "the degree to which a person believes that using a particular system would enhance his or her job performance" (Davis, 1989, p. 320). In e-learning systems, perceived usefulness is a significant determinant of continuance intention (Rahmi et al., 2018). In HCI-based research, flow is shown to be positively related to perceived usefulness and perceived ease of use of a learning management system (Sanchez-Franco, 
2010). To assess whether a system can be useful, a learner needs to experience the system without distraction. When a learner is in a flow state, the immersed and focused attention generates a stronger motivation to appreciate the usefulness of the e-learning system (Buil et al., 2019). Hence, we posit that:

H6. Flow experience is positively related to perceived usefulness.

H7. Perceived usefulness is positively related to continuance intention to use the learning management system.

\section{Gender and age as control variables}

Gender and age affect flow experience and its consequences. Past studies have shown that these two factors produce significant differences in the overall learning outcome model. For instance, Hsieh et al. (2016) investigated the consequences of flow experience with elementary school students, all of whom had online gaming experience. The participants were asked to play a resource allocation game and upon completion filled out a flow experience questionnaire. They found that there are considerable gender differences as the performance scores and flow experiences were higher for female students. Earlier, Novak and Hoffman (1997) identified that younger participants are associated with increased internet skill, and higher skill is conducive to triggering flow experience. However, Stavropoulos et al. (2013) reported in internet overuse older adolescents experienced more telepresence. Since age and gender are not the focal variables of the study and have been shown to affect the continued use intention of e-learning systems, the two variables are treated as control variables to accurately support the validity of inferences and to ensure the relationships between the predictors are not distorted (Bernerth \& Aguinis, 2016).

\section{Research methodology}

\section{Measures}

Past research has demonstrated that concentration, enjoyment, telepresence, and sense of control are reflective indicators of the flow construct. For instance, Siekpe (2005) reported that in a computer-mediated environment the flow construct is multidimensional and a reflective flow model fits better than a formative flow model. Similarly, Kwak et al. (2014) reported a second-order reflective flow model provided a good fit to investigate SNS flow experiences. Using a two-stage approach in PLS, their confirmatory factor analysis (CFA) results validated the second-order reflective flow construct. In addition, Wang et al. (2007) conducted a study on the sociability of retail websites using a second-order reflective flow construct to examine its effect on pleasure and utilitarian value, which confirmed the validity of the second-order reflective flow construct. Based on these studies, we adopt a reflective second-order factor to model the flow experience construct which consists of the concentration, enjoyment, telepresence, and control dimensions because according to Auld (2014), these dimensions were most frequently adopted and have been shown to produce good effect size in the reviewed studies of flow and continued intention to use e-learning. Measurement items in this research were adapted from previous studies as shown in the Appendix. We measured all items on a five-point agreement scale ( $1=$ strongly disagree, $5=$ strongly agree). E-learning engagement consists of usage intensity, which measures the weekly hours spent on using the 
e-learning system, and learning activities which captures the different types of interaction experienced by a learner.

\section{Common method bias}

We took four preventative measures to minimise common method bias (RodríguezArdura \& Meseguer-Artola, 2020). Firstly, the survey was checked by a bilingual teacher to ensure the standard and style of the English language is at the appropriate level to avoid any misinterpretation. Secondly, the surveys did not collect names, in order to further ensure anonymity for the survey's respondents. Thirdly, we let the respondents know that human ethics approval had been given and data gathered would be securely protected and aggregated. Lastly, we collected the data in multiple time frames from multiple classes.

We further performed Harman's one-factor test (Podsakoff et al., 2003) to evaluate whether any of the factors individually explained the majority of the variance. We obtained a single factor variance of $24.1 \%$. Moreover, the correlations among constructs were significantly less than 0.90 and the VIFs resulting from a full collinearity test were lower than 3.3 (Kock, 2015). Therefore, we are confident that common method bias is not significant enough in this study to affect the analysis.

\section{Data collection}

The survey instrument consists of three parts. Part A consists of demographic information, capturing gender, age, years at university, major and degree, usage intensity and experience with the types of learning activities. The e-learning system is a Moodle based learning management system supporting a blended learning environment. The learning activities include webinars, PowerPoint slides, online chat, online quizzes, online polling, blogs, video conferencing, videos, discussion forums, podcasts, wikis and games. Part B consists of the flow construct capturing concentration, enjoyment, telepresence and sense of control. Part $C$ measures the perceived usefulness, perceived ease of use and continuance intention constructs. The participants of this study comprised university students who use the Moodle learning management system for blended learning. The survey was distributed in a paper format to different classes in the university. We checked all the returned questionnaires to ensure they were properly completed. We obtained 120 returned surveys of which 92 were usable. Those unusable surveys were either non-responses, partially completed or non-differentiated in responses. The sample comprised $72.8 \%$ female participants and $27.2 \%$ male participants, which gives a female to male ratio of 2.6:1. The students were mainly in their second year (88\%) and 21-25 years of age. They represent 6 different business degrees and reported 35 different courses they had experienced recently with an e-learning system. Students on average spent $2.6 \mathrm{~h}$ per week (S.D. $=1.5 \mathrm{~h}$ ) and engaged with 2.3 activities (S.D. $=1.6)$ on the learning management system. Table 2 shows the demographic profile of the participants.

\section{Analysis and results}

We used Partial Least Squares (PLS) to analyse the data. Partial Least Squares (PLS) path modelling can handle complex causal relationships (Henseler et al., 2009), and fit both formative and reflective measurement models (Lohmoller, 1989). When the data 
Table 2 Demographic profile of the participants

\begin{tabular}{|c|c|c|c|}
\hline \multicolumn{2}{|c|}{ Sample characteristics } & \multirow{2}{*}{$\begin{array}{l}(\mathbf{N}=\mathbf{9 2}) \\
25\end{array}$} & \multirow{2}{*}{$\begin{array}{l}\text { Percentage \% } \\
27.2\end{array}$} \\
\hline Gender & Male & & \\
\hline & Female & 67 & 72.8 \\
\hline \multirow[t]{4}{*}{ Age } & $16-20$ & 9 & 9.8 \\
\hline & $21-25$ & 80 & 87.0 \\
\hline & $26-30$ & 1 & 1.1 \\
\hline & $36-40$ & 2 & 2.2 \\
\hline \multirow[t]{4}{*}{ Years at university } & 2 & 81 & 88.0 \\
\hline & 3 & 5 & 5.4 \\
\hline & 4 & 5 & 5.4 \\
\hline & 5 & 1 & 1.1 \\
\hline \multirow[t]{4}{*}{ Usage per week* } & Less than $2 \mathrm{~h}$ & 71 & 78.0 \\
\hline & $2-4 h$ & 15 & 16.5 \\
\hline & $5-6 h$ & 2 & 2.2 \\
\hline & $7-9 h$ & 3 & 3.3 \\
\hline \multirow[t]{8}{*}{ Learning activities } & 1 & 37 & 40.2 \\
\hline & 2 & 29 & 31.5 \\
\hline & 3 & 7 & 7.6 \\
\hline & 4 & 13 & 14.1 \\
\hline & 5 & 3 & 3.3 \\
\hline & 6 & 1 & 1.1 \\
\hline & 9 & 1 & 1.1 \\
\hline & 10 & 1 & 1.1 \\
\hline \multirow[t]{6}{*}{ Degree } & BACCY & 49 & 53.3 \\
\hline & BBA & 30 & 32.6 \\
\hline & BECS & 8 & 8.7 \\
\hline & BFIN & 2 & 2.2 \\
\hline & MBA & 2 & 2.2 \\
\hline & BPS & 1 & 1.1 \\
\hline
\end{tabular}

*Missing data

population is unknown, PLS is a recommended option (Sarstedt et al., 2016). Sosik et al. (2009) and Monecke and Leisch (2012) consider PLS-SEM as a type of modelling technique which has minimum demands on measurement scales, sample sizes and residual distributions. PLS is suggested when research is constrained by a low level of information. The PLS method was adopted in this study because firstly it fits our small data size, secondly, some of the data did not exhibit normal distributions and lastly, it fits the research criteria to explore and identify potential relationships as is recommended (Hair Jr et al., 2014). With three main effect predictors, an effect size of 0.15 , an $\alpha$ of 0.05 and a power of 0.8 , the estimated sample size is 71 (Soper, 2019). Our sample size of 92 exceeds the minimum requirement and is thus adequate for PLS analysis. We adopted a two-step procedure to confirm data reliability and validity. The first step was to examine the data in the measurement model. The second step was to determine the path coefficients in the structural model. In the measurement model, we evaluated the convergent validity and discriminant validity of the constructs. In the PLS evaluation, we controlled for the effects of gender and age. We used a repeated indicators approach for the second-order construct. We adopted the bootstrapping re-sampling procedure in SmartPLS (Ringle, 
2010) to verify the structural model and to determine the significance of the path coefficients as recommended by Hair Jr et al. (2014).

\section{Measurement validity}

To validate the first-order constructs, Hair Jr et al. (2014) suggest using composite scale reliability, Cronbach's alpha and average variance extracted (AVE) to assess internal consistency and reliability. Composite reliability is a stable measure which considers whether the outer loadings are less sensitive to the number of items in the scale. Table 3 depicts the composite reliability values which are well above 0.75 ; a value greater than 0.6 is desirable. The AVE values in Table 4 are all above 0.50 , demonstrating that the constructs adequately explain the variance in the model. AVE for the second-order construct is calculated by averaging the squared multiple correlations for the first-order indicators (MacKenzie et al., 2011).

We examined the standardised outer loadings of the constructs to check whether the associated indicators in the measurement model have much in common. As depicted in Table 3, the standardised loadings for the first-order constructs ranged from 0.69 to 0.93 and all were significant; convergence validity of the measures is thus confirmed.

Table 3 Construct validity measured by items loading and reliability measured by composite reliability

\begin{tabular}{|c|c|c|c|c|c|}
\hline Constructs & Items & Loadings & Standard Error & T Statistics & CR \\
\hline \multirow[t]{4}{*}{ FLOW (Second order) } & $\mathrm{CON}$ & 0.675 & 0.055 & 12.24 & 0.88 \\
\hline & CTR & 0.692 & 0.035 & 19.41 & \\
\hline & ENJ & 0.851 & 0.026 & 32.33 & \\
\hline & TEL & 0.520 & 0.056 & 9.20 & \\
\hline \multirow[t]{4}{*}{ Flow-concentration (CON) } & CON1 & 0.730 & 0.051 & 14.08 & 0.87 \\
\hline & CON2 & 0.856 & 0.029 & 29.34 & \\
\hline & CON3 & 0.812 & 0.033 & 24.00 & \\
\hline & CON4 & 0.759 & 0.034 & 22.25 & \\
\hline \multirow[t]{4}{*}{ Flow-enjoy (ENJ) } & ENJ1 & 0.893 & 0.014 & 62.27 & 0.95 \\
\hline & ENJ2 & 0.928 & 0.011 & 81.70 & \\
\hline & ENJ3 & 0.914 & 0.013 & 66.12 & \\
\hline & ENJ4 & 0.872 & 0.021 & 41.53 & \\
\hline \multirow[t]{2}{*}{ Flow-telepresence (TEL) } & TEL2 & 0.926 & 0.01 & 92.44 & 0.91 \\
\hline & TEL3 & 0.898 & 0.025 & 35.53 & \\
\hline \multirow[t]{3}{*}{ Flow-control (CTR) } & CTR1 & 0.750 & 0.040 & 18.49 & 0.86 \\
\hline & CTR2 & 0.851 & 0.024 & 34.63 & \\
\hline & CTR3 & 0.848 & 0.015 & 54.63 & \\
\hline \multirow[t]{3}{*}{ Perceived usefulness (PU) } & PU1 & 0.819 & 0.029 & 27.75 & 0.83 \\
\hline & PU2 & 0.834 & 0.026 & 31.16 & \\
\hline & PU3 & 0.689 & 0.035 & 19.65 & \\
\hline \multirow[t]{2}{*}{ Perceived ease of use (PEOU) } & PEOU1 & 0.851 & 0.033 & 25.27 & 0.86 \\
\hline & PEOU2 & 0.887 & 0.021 & 42.36 & \\
\hline \multirow[t]{2}{*}{ Continuance intention (Cl) } & $\mathrm{Cl} 1$ & 0.896 & 0.015 & 56.34 & 0.88 \\
\hline & $\mathrm{Cl} 2$ & 0.868 & 0.026 & 33.20 & \\
\hline \multirow[t]{2}{*}{ E-learning engagement (LE) } & LE1 & 0.783 & 0.134 & 5.87 & 0.75 \\
\hline & LE2 & 0.767 & 0.162 & 4.74 & \\
\hline
\end{tabular}

All loadings were significant at $p<0.001$. $C R$ composite reliability 
Table 4 Inter-construct correlations, squared root of AVEs and descriptive statistics

\begin{tabular}{lllllllllllll}
\hline Constructs & AVE & Mean & SD & CI & FLOW & CON & CTR & ENJ & TEL & PEOU & PU & LE \\
\hline CI & 0.78 & 4.05 & 0.63 & $\mathbf{0 . 8 8}$ & & & & & & & \\
FLOW & 0.51 & 3.28 & 0.54 & 0.44 & $\mathbf{0 . 7 1}$ & & & & & & \\
CON & 0.63 & 3.40 & 0.63 & 0.24 & 0.68 & $\mathbf{0 . 7 9}$ & & & & & & \\
CTR & 0.67 & 3.17 & 0.73 & 0.45 & 0.68 & 0.26 & $\mathbf{0 . 8 2}$ & & & & & \\
ENJ & 0.81 & 3.38 & 0.77 & 0.30 & 0.86 & 0.49 & 0.34 & $\mathbf{0 . 9 0}$ & & & & \\
TEL & 0.83 & 2.68 & 0.98 & 0.23 & 0.52 & 0.02 & 0.40 & 0.34 & $\mathbf{0 . 9 1}$ & & & \\
PEOU & 0.76 & 3.86 & 0.65 & 0.41 & 0.20 & 0.50 & 0.37 & 0.31 & 0.09 & $\mathbf{0 . 8 7}$ & & \\
PU & 0.61 & 3.89 & 0.54 & 0.63 & 0.48 & 0.25 & 0.60 & 0.24 & 0.34 & 0.40 & $\mathbf{0 . 7 8}$ & \\
LE & 0.60 & 1.58 & 0.73 & 0.04 & 0.20 & 0.17 & 0.05 & 0.20 & 0.13 & -0.05 & 0.16 & 0.77 \\
\hline Alcorrat
\end{tabular}

All correlations were significant at $p<0.001$. Diagonal elements are square roots of average variance extracted; off-diagonal elements are correlations

Table 5 Path coefficients and the results of the hypotheses tests

\begin{tabular}{|c|c|c|c|c|c|}
\hline & $\mathrm{R}^{2}$ & Path & Std. Error & T Statistics & Hypotheses \\
\hline $\mathrm{Age} \longrightarrow \mathrm{Cl}$ & 0.49 & 0.05 & 0.03 & $1.45^{*}$ & ns \\
\hline Gender $\longrightarrow \mathrm{Cl}$ & & 0.10 & 0.04 & $2.32^{* *}$ & \\
\hline $\mathrm{LE}->\mathrm{Cl}$ & & -0.03 & 0.05 & $0.78^{*}$ & ns \\
\hline $\mathrm{FLOW} \longrightarrow \mathrm{Cl}$ & & 0.13 & 0.04 & $2.27^{* *}$ & H1:supported \\
\hline $\mathrm{PEOU} \longrightarrow \mathrm{Cl}$ & & 0.10 & 0.05 & $1.75^{*}$ & H4: not supported \\
\hline $\mathrm{PU} \longrightarrow \mathrm{Cl}$ & & 0.45 & 0.04 & $9.35^{* * *}$ & H7: supported \\
\hline $\mathrm{LE}->\mathrm{FLOW}$ & & 0.23 & 0.05 & $4.61^{* * *}$ & H2a: supported \\
\hline $\mathrm{FLOW}^{*} \mathrm{LE} \longrightarrow \mathrm{Cl}$ & & -0.22 & 0.05 & $4.20^{* * *}$ & H2b: supported \\
\hline $\mathrm{PEOU} \longrightarrow \mathrm{PU}$ & 0.27 & 0.23 & 0.05 & $4.54^{* * *}$ & H5: supported \\
\hline $\mathrm{FLOW} \longrightarrow \mathrm{PU}$ & & 0.38 & 0.04 & $7.69^{* * *}$ & H6: supported \\
\hline $\mathrm{PEOU} \longrightarrow \mathrm{FLOW}$ & 0.27 & 0.48 & 0.06 & $7.49^{* * *}$ & H3: supported \\
\hline $\mathrm{FLOW} \longrightarrow \mathrm{CON}$ & 0.46 & 0.68 & 0.05 & $12.39^{* * *}$ & \\
\hline $\mathrm{FLOW} \longrightarrow \mathrm{CTR}$ & 0.48 & 0.69 & 0.03 & $17.87^{* * *}$ & \\
\hline FLOW $\rightarrow$ ENJ & 0.73 & 0.86 & 0.02 & $37.50^{* * *}$ & \\
\hline FLOW $\rightarrow$ TEL & 0.27 & 0.52 & 0.05 & $9.28^{* * *}$ & \\
\hline
\end{tabular}

Path Coefficient ${ }^{*}=$ not significant; ${ }^{* *}$ significant at $\mathrm{p}<0.05 ;{ }^{* * *}$ significant at $\mathrm{p}<0.001$

Items TEL1 and TEL4 were removed from the construct due to low loading. We show in Table 4 the sample mean, standard deviation, and inter-correlation coefficients among the variables; the diagonal terms represent the square roots of the average variance extracted. The inter-correlation values were mostly moderate, ranging from 0.00 to 0.63 and lower than the reliability coefficients, showing good discriminant validity. VIFs obtained by the inverse latent matrix technique for all the latent variables in the model were all less than 3 . Table 4 shows the correlations between main constructs were less than 0.7, thus according to Hair (2010) the risk of multicollinearity is low. Furthermore, Table 4 shows the shared variances were all smaller than the square roots of the average variance extracted, hence discriminant validity is confirmed (Fornell \& Larcker, 1981).

\section{Results}

Table 5 shows the results of the PLS analysis for the overall structural model. The results show that all the hypotheses except $\mathrm{H} 4$ were supported. The structural model was found 
to have 49,27 and $27 \%$ explanatory power for continuance intention (CI), perceived usefulness (PU) and flow experience (FLOW) respectively. The total effects (direct and indirect) on continuance intention (CI) were $0.29,0.25$ and 0.45 for flow, perceived ease of use and perceived usefulness respectively. Perceived usefulness is a strong factor affecting the continuance intention to use the learning management system while flow and perceived ease of use have significant direct and indirect impact on continuance intention. Gender as a control variable influences the continuance intention to use an e-learning system but age has no significant effect. Female students have a higher continued intention to use the learning management system than male students. The SRMR is a measure of the estimated model fit. It is the average of standardised residuals between the observed and the hypothesised covariance matrices. The current study model's SRMR was 0.049 which is considered a good fit (Hu \& Bentler, 1998).

An important aspect of the current study is examining whether flow experience could be heightened by increasing e-learning engagement as stated in hypothesis H2a. Analysis using PLS confirms the direct effect of e-learning engagement on the flow experience $(\beta=0.23, p<0.001)$. Hence, H2a is supported.

Next, the study investigated the moderation effect of e-learning engagement on flow to ascertain the dual effect of flow experience upon continuance intention to use the learning management system. We operationalised the moderation effect by including the interaction terms in the PLS model. Table 5 depicts the outcome of the analysis. The interaction term (Flow $\times$ LE) is significant $(\beta=-0.22, p<0.001)$ and the path coefficient of the interaction term is negative. Hence, increased e-learning engagement weakens the impact of flow experience on continuance intention to use the e-learning system, thus supporting hypothesis $\mathrm{H} 2 \mathrm{~b}$. To ascertain the effect of the model containing the moderator, we used the hierarchical process by establishing a base model without a moderator and computed the change in $\mathrm{R}^{2}$ after the moderator was included (Limayem \& Cheung, 2008). $\Delta R^{2}$ was found to be significant with $F(1,89)=8.8, p<0.05$ and a low moderate effect size of $\mathrm{f}^{2}=0.1$. Hence, we confirm that the moderator model possessed significantly higher explanatory power. The formulas for calculating effect size and Pseudo $\mathrm{F}$ were obtained from Chin et al. (2003) and Carte and Russell (2003).

\section{Discussion}

This study investigated the nature of flow experience in driving learners' continuance intention to use a learning management system in a blended learning environment with e-learning engagement as a moderator. The model is validated with all the path coefficients being significant (except H4) and demonstrated that flow positively affects continuance intention $(\mathrm{H} 1)$. The direct impact of flow on $\mathrm{CI}(\beta=0.13, \mathrm{p}<0.05)$ is in line with previous findings (Davis \& Wong, 2007; Hong et al., 2019). By adopting a second-order flow construct, this study gives stronger psychometric strength and validity to the flow relationship (Sarstedt \& Wilczynski, 2009). Overall, the positive impact of flow on the continuance relationship fits well with the self-reinforcement theory which posits that the stimuli produced by the system-user engagement actuate the motivation for sustaining the activity (Bandura, 1976; Novak \& Hoffman, 1997). As students interact with the learning management system, the flow experiences of enjoyment, telepresence, sense 
of control and concentration derived from e-learning activities reinforce their intrinsic motivation in driving e-learning system continuance.

In the literature, the reported findings on the relationship between flow experience and continuance intention to use e-learning systems are mixed (Auld, 2014). The inconsistency is partly attributed to the presence of unexamined moderators (Sun \& Zhang, 2006). The presence of moderators can weaken or even reverse the direction of a relation (Andersson et al., 2014). In this study, e-learning engagement's action as a moderator has been identified. The finding showed that increased e-learning engagement heightens overall flow experience. As learners engage intensively with different learning activities they are more likely to encounter challenging and enjoyable tasks that are conducive to heightening their flow state (Esteban-Millat et al., 2018; Rodríguez-Ardura \& Meseguer-Artola, 2017). The finding further showed that increased e-learning engagement weakens the impact of flow on continuance intention to use the learning management system. The negative interaction of the finding supports the proposition that the mixed relationship between flow and continued intention in past studies is caused by unexamined moderators, as negative interaction can significantly attenuate the relationship if the samples collected were biased towards a highly engaging group (Hong et al., 2019; Rodríguez-Ardura \& Meseguer-Artola, 2019). Since there is a non-significant relationship between e-learning engagement and continuance intention as depicted in Table 5, the weakening effect of flow on continuance intention is not caused by the moderator decreasing the level of continuance intention. Hence, we conclude that flow exhibits a dual effect in the e-learning system continuance model.

The negative interaction effect implies that as e-learning engagement increases, students decrease their emphasis on channelling the flow experience into intrinsic motivation to influence their decision on continuous use intention, though they still attain heightened flow experiences. According to the dynamic motivation and changes theory, learners emphasise different motivations during different stages of learning (Brown \& Charlier, 2013; Song \& Keller, 2001). Cole et al. (2004) proposed that the composition of learning motivation is dynamic, i.e., it changes over time and that individuals progress through various motivational states. According to the stage-based model of learning motivation, students have different awareness of intrinsic motivators (such as flow experience) and extrinsic motivators (such as usefulness) at different learning states. These learning motivations will influence their decision-making processes on their effort applied to a learning activity (Cole et al., 2004). As learning motivation progresses, they engage in more learning activities and their motivation move to the action state which tends to align with more extrinsic factors such as achieving a better performance outcome, score or achieving learning goals (Cole et al., 2004; Lin \& Chen, 2017). The changes in motivation dynamic is also explained by the over-justification effect where an external incentive decreases a person's intrinsic motivation to perform a behaviour (Deci, 1971). In a blended learning environment, it is common practice to have tasks and activities that are mandatory and weighted in the course assessments which will heighten extrinsic motivation (Ortega-Arranz et al., 2019). Subsequently, students in this study place less emphasis on the influence of intrinsic motivators on their continued use intention decision. The strength of these motivators is influenced by individual characteristics, learning styles and interactive experiences with the type of e-learning activities (Hartnett, 2016). The motivation factors are re-emphasised dynamically and complement one another to support 
the decision on continued use intention (Hartnett et al., 2011). For instance, the studies by Mahnken et al. (2011) and Goh and Clapham (2014) revealed that a more extensive use of e-learning is triggered by extrinsic motivation rather than intrinsic motivation. In sum, this discussion provides a possible explanation of the negative interaction of e-learning engagement on the impact of flow experience on continued use intention which is not well reported in previous studies (Auld, 2014). For researchers, future studies should critically examine the link between flow experience and the dynamic exchange between different forms of motivators over times and learning modes.

\section{Implications and limitations}

The present study provides several implications for practice and future research in manipulating flow and encouraging learners to continue to use the learning management system in a blended learning environment.

From a theoretical perspective, this study presented a dual motivation model based on two key factors: flow represents the intrinsic motivation and perceived usefulness represents the extrinsic motivation (Deci \& Ryan, 1985). The results further support a mediated moderation model with a more complex interaction dynamic between e-engagement and flow as revealed by the dual effect of flow. The current model could further improve to include how engagement with LMS affects learning performance to achieve a more complete blended LMS learning model (Avcı \& Ergün, 2019). The findings highlight the importance of perceived usefulness and flow in predicting students' continuance intention toward LMS. Researchers should continue to investigate the types of learning technology and activities that increase perceived usefulness and match the specific dimensions of flow experience against learning activities. In this way, we will gain the ability to control flow dimensions and thereby increase students' continuance intention toward LMS. Similarly, researchers should investigate the pedagogical factors and activities that contribute to e-engagement in a blended learning environment (Henrie et al., 2015). Specifically, researchers should investigate the circumstances in which e-engagement and flow interact positively and how to overcome negative interaction.

There are practical implications for instructors. First, as an extrinsic motivator perceived usefulness has a strong effect on students' continued intention to use the learning management system. Instructors should therefore organise and clearly communicate their blended learning activities in LMS in a way that explicitly relates to the expectation of the course learning objectives. In this study as shown in "Appendix" Fig. 2, students indicated PowerPoint slides as the most frequent activities in the blended LMS learning environment. As a minimum practice, instructors should continue to upload PowerPoint slides to enhance the learning content understanding and heighten students' behavioural engagement in preparation for the lecture and for interactive lecture activities (Heilporn et al., 2021). Second, perceived ease of use in this study has no direct impact on continuance intention. One plausible explanation is that the current samples were mostly second year students and they are familiar with the activities in the LMS. However, instructors should be aware that activities that are organised for senior students may not necessarily achieve the same usability experience for the first-year students. Perceived ease of use plays a pivotal role in the interaction dynamic as it facilitates the experience of flow and the realisation of learning usefulness which all have an impact on students' intention to use the learning management system. Instructors must therefore ensure 
adequate training and support for students who are not technology savvy when introducing unfamiliar learning activities. Lastly, different learning activities affect students' flow state and their engagement experience (Wang et al., 2020). In this study, the top three learning activities are viewing PowerPoint slides, taking a quiz and participating in a discussion forum. Instructors should be aware that though these activities may be responsible for inducing flow and generating student engagement, their impact can be different. For example, with respect to the concentration dimension of flow, taking a quiz would require shorter concentration than viewing PowerPoint slides where longer concentration may be required. Similarly, participating in a discussion forum may require more emotional engagement than taking a quiz where cognitive engagement is more involved (Zainuddin et al., 2020). Therefore, in term of designing learning activities, instructors should follow best practice to use a design tool to determine the desired dimensions to be activated in flow experience and students' engagement in order to achieve the desired learning outcomes (Gao et al., 2019; Zanjani, 2015).

While several new findings were presented, this study has some limitations. First, the current findings are limited to a cross-sectional study in a blended learning environment using a Moodle LMS covering multiple business courses and do not reflect a longitudinal trend nor can they be generalised to a fully online learning environment in other disciplines. Fully online and blended learning have different interaction dynamics that will differ in students' motivation and engagement (Blaine, 2019). Second, the e-engagement measure in this study is a quantitative measure of activities and usage. The qualitative aspects of engagement and other forms of engagement such as cognitive, cultural, and emotional engagement were not included (Henrie et al., 2015; Schindler et al., 2017). Third, in this study the participants were full-time and young students from a university; working adults and senior learners from different cultural backgrounds are sensitive to time, skills, work-life balance, and organisation goals which require further study (Granić \& Marangunić, 2019; Heo et al., 2010; Kothgassner et al., 2018). Fourth, this study controlled for gender and age but did not consider many other individual factors such as learning styles, academic performance, stress and fatigue level (Rodríguez-Ardura \& Meseguer-Artola, 2019). Different individual factors contribute to the dynamic of flow relationships and should be accounted for in future models. Fifth, the sample size in this study is not large which might affect some of the findings. Future study should use a larger sample size to improve the effect size of the study. Lastly, self-report questionnaires, which can be subjective, were used to measure the flow constructs. Alternatively, objective methods that capture affective states such as experience sampling using wearable sensors can be adopted (Giannakos et al., 2020).

\section{Conclusions}

This study leads us to understand the dynamic of e-engagement and flow experience on the continuance with a learning management system in a blended learning environment. First, flow experience operationalised by a second-order construct and integrated with the technology acceptance model containing dual motivation factors provides a good exploratory research model to understand e-learning continuance intention. Instructors can now better understand the effect of engagement with the learning activities within the LMS on flow experience and could enhance these activities with more certainty in a blended learning environment (Granić \& Marangunić, 2019). Second, engagement affects flow experience, which is a significant antecedent to perceived usefulness, thereby establishing interplay between an 
intrinsic motivator and an extrinsic motivator where instructors will need to strike a balance in adopting blended learning LMS delivery. Third, as flow experience mediates between perceived ease of use and continued use intention, instructors must ensure adequate training and illustrations are available to students to perform the required activities in the LMS. This will improve system ease of use and increase continued use intention through flow experience (Oliveira, 2019; Zhao et al., 2020). Lastly, instructors should be aware of the possibility that activities in LMS that increase engagement might improve flow experience but at the same time weaken the influence on e-learning system continuance intention if the engagement is not intrinsically motivated.

\section{Appendix A}

See Table 6 and Fig. 2.

Table 6 Construct measurements

\begin{tabular}{|c|c|c|}
\hline \multicolumn{2}{|l|}{ Constructs } & \multirow{3}{*}{$\begin{array}{l}\text { Source } \\
\text { Guo et al., (2016) }\end{array}$} \\
\hline Continuance Intention (CI) & $\begin{array}{l}\text { I am willing to participate in other courses using the } \\
\text { e-learning system. (CI1) }\end{array}$ & \\
\hline & I will continue to use the e-learning system in my study. (Cl2) & \\
\hline \multirow[t]{3}{*}{ Perceived usefulness (PU) } & $\begin{array}{l}\text { Using the e-learning system improves my performance in my } \\
\text { studies. (PU1) }\end{array}$ & \multirow[t]{3}{*}{ Davis (1989) } \\
\hline & $\begin{array}{l}\text { Using the e-learning system in my studies increases my } \\
\text { productivity. (PU2) }\end{array}$ & \\
\hline & I find the e-learning system to be useful in my studies. (PU3) & \\
\hline Perceived ease of use (PEOU) & $\begin{array}{l}\text { My interaction with the e-learning system is clear and under- } \\
\text { standable. (PEOU1) } \\
\text { I find the e-learning system to be easy to use. (PEOU2) } \\
\text { Interacting with the e-learning system does not require a lot } \\
\text { of my mental effort. (PEOU3*) }\end{array}$ & Davis (1989) \\
\hline \multirow[t]{4}{*}{ Concentration (CON) } & $\begin{array}{l}\text { I was intensely absorbed during my e-learning activities. } \\
\text { (CON1) }\end{array}$ & \multirow[t]{4}{*}{ Ghani et al., (1991) } \\
\hline & $\begin{array}{l}\text { My attention was very focused during my e-learning activi- } \\
\text { ties. (CON2) }\end{array}$ & \\
\hline & I concentrated fully during my e-learning activities. (CON3) & \\
\hline & $\begin{array}{l}\text { I was deeply engrossed during my e-learning activities. } \\
\text { (CON4) }\end{array}$ & \\
\hline \multirow[t]{4}{*}{ Enjoyment (ENJ) } & I found my e-learning activities interesting. (ENJ1) & \multirow[t]{4}{*}{ Ghani et al., (1991) } \\
\hline & I found my e-learning activities enjoyable. (ENJ2) & \\
\hline & I found my e-learning activities exciting. (ENJ3) & \\
\hline & I found my e-learning activities fun. (ENJ4) & \\
\hline \multirow[t]{4}{*}{ Tele-presence (TEL) } & During e-learning activities, I often forgot where I was. (TEL1) & \multirow[t]{4}{*}{ Novak et al., (2000) } \\
\hline & $\begin{array}{l}\text { During e-learning activities, I felt I was in a virtual classroom } \\
\text { created by the e-learning system. (TEL2) }\end{array}$ & \\
\hline & $\begin{array}{l}\text { After the e-learning activities, I felt like I had come back from } \\
\text { a'virtual classroom' after a journey. (TEL3) }\end{array}$ & \\
\hline & $\begin{array}{l}\text { During the e-learning activities, I felt that the virtual class- } \\
\text { room was more real for me than the "real classroom". (TEL4) }\end{array}$ & \\
\hline \multirow[t]{3}{*}{ Control (CTR) } & $\begin{array}{l}\text { During e-learning activities, I felt total comprehension of } \\
\text { what I was learning. (CTR1) }\end{array}$ & \multirow[t]{3}{*}{ Guo and Ro (2008) } \\
\hline & $\begin{array}{l}\text { During e-learning activities, I felt like I could control my learn- } \\
\text { ing. (CTR2) }\end{array}$ & \\
\hline & $\begin{array}{l}\text { During e-learning activities, I felt in total control of my mind. I } \\
\text { had a feeling of total control. (CTR3) }\end{array}$ & \\
\hline
\end{tabular}

*Item removed 


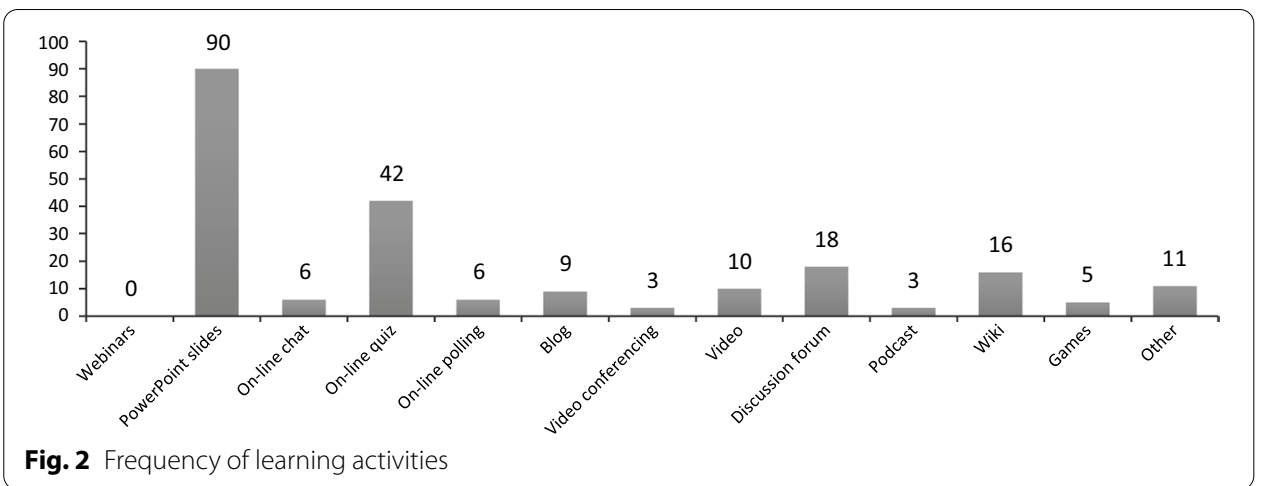

Acknowledgements

Not applicable.

Authors' contributions

On behalf of all authors, the corresponding author states that all the authors have contributed equally. All authors read and approved the final manuscript.

\section{Author information}

Tiong-Thye Goh is a senior lecturer in Information Management at Victoria University of Wellington, New Zealand. Dr Goh current research includes social media, emotion computing, classification, education technology, analytics, and user behaviour. Dr Goh's publications appeared in Journal of Business Research, Journal of Information Systems Education, Commerce Research, British Journal of Educational Technology, and Journal of Educational Technology \& Society.

Bing Yang is currently a full professor of computing with the School of Education, Hubei University Wuhan China. Professor Yang's research involves computer networking, educational technology, e-commerce and big data mining. He has published extensive research in computer science journal, Chinese journal of computer and other international conferences and workshops.

\section{Funding}

Not applicable.

\section{Availability of data and materials}

Data available on request from the authors.

\section{Declarations}

\section{Competing interests}

On behalf of all authors, the corresponding author states that all the authors they have no competing interests.

\section{Author details}

${ }^{1}$ School of Information Management, Victoria University of Wellington, P.O. Box 600, Wellington, New Zealand. ${ }^{2}$ School of Education, Hubei University, 368 Youyi Avenue, Wuchang, Wuhan, Hubei, China.

Received: 15 March 2021 Accepted: 5 July 2021

Published online: 15 September 2021

\section{References}

Andersson, U., Cuervo-Cazurra, A., \& Nielsen, B. B. (2014). From the editors: Explaining interaction effects within and across levels of analysis. In: Springer

Ashrafi, A., Zareravasan, A., Rabiee Savoji, S., \& Amani, M. (2020). Exploring factors influencing students' continuance intention to use the learning management system (LMS): a multi-perspective framework. Interactive Learning Environments. https://doi.org/10.1080/10494820.2020.1734028

Auld, D. P. (2014). Flow and learning in computer-mediated learning environments: a meta-analytic review. (Doctoral thesis). Fordham University, Ann Arbor. ProQuest Dissertations \& Theses Global database. (3632075)

Avcı, Ü., \& Ergün, E. (2019). Online students'LMS activities and their effect on engagement, information literacy and academic performance. Interactive Learning Environments. https://doi.org/10.1080/10494820.2019.1636088

Bandura, A. (1976). Self-reinforcement: theoretical and methodological considerations. Behaviorism, 4(2), 135-155.

Bernerth, J. B., \& Aguinis, H. (2016). A critical review and best-practice recommendations for control variable usage. Personnel Psychology, 69(1), 229-283. 
Blaine, A. M. (2019). Interaction and presence in the virtual classroom: an analysis of the perceptions of students and teachers in online and blended Advanced Placement courses. Computers \& Education, 132, 31-43. https://doi.org/ 10.1016/j.compedu.2019.01.004

Brown, K. G., \& Charlier, S. D. (2013). An integrative model of e-learning use: leveraging theory to understand and increase usage. Human Resource Management Review, 23(1), 37-49. https://doi.org/10.1016/j.hrmr.2012.06.004

Buil, I., Catalán, S., \& Martínez, E. (2019). The influence of flow on learning outcomes: an empirical study on the use of clickers. British Journal of Educational Technology, 50(1), 428-439.

Carte, T. A., \& Russell, C. J. (2003). In pursuit of moderation: nine common errors and their solutions. MIS quarterly, 479-501

Cheng, Y.-M. (2013). Exploring the roles of interaction and flow in explaining nurses' e-learning acceptance. Nurse Education Today, 33(1), 73-80.

Chin, W. W. Marcolin, B. L.\& \& Newsted, P. R. (2003). A partial least squares latent variable modeling approach for measuring interaction effects: results from a Monte Carlo simulation study and an electronic-mail emotion/adoption study. Information Systems Research, 14(2), 189-217.

Choudhury, S., \& Pattnaik, S. (2020). Emerging themes in e-learning: a review from the stakeholders' perspective. Computers \& Education, 144, 103657. https://doi.org/10.1016/j.compedu.2019.103657

Cole, M. S., Harris, S. G., \& Feild, H. S. (2004). Stages of learning motivation: development and validation of a measure. Journal of Applied Social Psychology, 34(7), 1421-1456.

Csikszentmihalyi, M. (1975). Beyond boredom and anxiety. The Jossey-Bass behavioral science series Show all parts in this series

Csikszentmihalyi, M., \& Asakawa, K. (2016). Universal and cultural dimensions of optimal experiences. Japanese Psychological Research, 58(1), 4-13.

Davis, F. D. (1989). Perceived usefulness, perceived ease of use, and user acceptance of information technology. MIS Quarterly, 13(3), 319-340. https://doi.org/10.2307/249008

Davis, R., \& Wong, D. (2007). Conceptualizing and measuring the optimal experience of the eLearning environment* Decision Sciences Journal of Innovative Education, 5(1), 97-126. https://doi.org/10.1111/j.1540-4609.2007.00129.x

Deci, E. L. (1971). Effects of externally mediated rewards on intrinsic motivation. Journal of Personality and Social Psychology, 18(1), 105

Deci, E. L., \& Ryan, R. M. (1985). Operant and attributional theories. In Intrinsic motivation and self-determination in human behavior (pp. 179-211): Springer

dos Santos, W. O., Bittencourt, I. I., Isotani, S., Dermeval, D., Marques, L. B., \& Silveira, I. F. (2018). Flow theory to promote learning in educational systems: is it really relevant? Revista Brasileira De Informática Na Educação, 26(02), 29.

Eraslan Yalcin, M., \& Kutlu, B. (2019). Examination of students' acceptance of and intention to use learning management systems using extended TAM. British Journal of Educational Technology, 50(5), 2414-2432. https://doi.org/10.1111/ bjet.12798

Esteban-Millat, I., Martínez-López, F. J., Pujol-Jover, M., Gázquez-Abad, J. C., \& Alegret, A. (2018). An extension of the technology acceptance model for online learning environments. Interactive Learning Environments, 26(7), 895-910. https://doi.org/10.1080/10494820.2017.1421560

Fornell, C., \& Larcker, D. F. (1981). Evaluating structural equation models with unobservable variables and measurement error. Journal of Marketing Research, 18(1), 39-50. https://doi.org/10.2307/3151312

Gao, B., Wan, Q., Chang, T., \& Huang, R. (2019). A framework of learning activity design for flow experience in smart learning environment. In Foundations and trends in smart learning (pp. 5-14): Springer

Ghani, J. A., Supnick, R., \& Rooney, P. (1991). The experience of flow in computer-mediated and in face-to-face groups. Paper presented at the ICIS

Giannakos, M. N., Sharma, K., Papavlasopoulou, S., Pappas, I. O., \& Kostakos, V. (2020). Fitbit for learning: towards capturing the learning experience using wearable sensing. International Journal of Human-Computer Studies, 136, 102384. https://doi.org/10.1016/j.ijhcs.2019.102384

Goh, J., \& Clapham, M. (2014). Attitude to e-learning among newly qualified doctors. The Clinical Teacher, 11(1), 20-23.

Granić, A., \& Marangunić, N. (2019). Technology acceptance model in educational context: a systematic literature review. British Journal of Educational Technology, 50(5), 2572-2593. https://doi.org/10.1111/bjet.12864

Guo, Y. M., \& Ro, Y. K. (2008). Capturing flow in the business classroom. Decision Sciences Journal of Innovative Education, 6(2), 437-462. https://doi.org/10.1111/j.1540-4609.2008.00185.x

Guo, Z., Xiao, L., Van Toorn, C., Lai, Y., \& Seo, C. (2016). Promoting online learners' continuance intention: an integrated flow framework. Information \& Management, 53(2), 279-295. https://doi.org/10.1016/j.im.2015.10.010

Hair, J. F. (2010). Multivariate data analysis (7th ed.). Prentice Hall.

Hair Jr, J. F., Hult, G. T. M., Ringle, C., \& Sarstedt, M. (2014). A primer on partial least squares structural equation modeling (PLSSEM): Sage Publications

Hartnett, M. (2016). The importance of motivation in online learning. In Motivation in online education (pp. 5-32): Springer

Hartnett, M., St. George, A., \& Dron, J. (2011). Examining motivation in online distance learning environments: complex, multifaceted, and situation-dependent. International Review of Research in Open and Distributed Learning, 12(6), 20-38. https://doi.org/10.19173/irrodl.v12i6.1030

Hayes, A. F. (2017). Introduction to mediation, moderation, and conditional process analysis: A regression-based approach

Heilporn, G., Lakhal, S., \& Bélisle, M. (2021). An examination of teachers'strategies to foster student engagement in blended learning in higher education. International Journal of Educational Technology in Higher Education, 18(1), 25. https://doi.org/10.1186/s41239-021-00260-3

Henrie, C. R., Halverson, L. R., \& Graham, C. R. (2015). Measuring student engagement in technology-mediated learning: a review. Computers \& Education, 90, 36-53.

Henseler, J., Ringle, C., \& Sinkovics, R. (2009). The use of partial least squares path modeling in international marketing in Rudolf R. Sinkovics, Pervez N. Ghauri (ed.) New Challenges to International Marketing (Advances in International Marketing, Volume 20). 277-319. doi:citeulike-article-id:9257769 
Heo, J., Lee, Y., Pedersen, P. M., \& McCormick, B. P. (2010). Flow experience in the daily lives of older adults: an analysis of the interaction between flow, individual differences, serious leisure, location, and social context. Canadian Journal on Aging/la Revue Canadienne Du Vieillissement, 29(3), 411-423.

Ho, L.-A., \& Kuo, T.-H. (2010). How can one amplify the effect of e-learning? An examination of high-tech employees' computer attitude and flow experience. Computers in Human Behavior, 26(1), 23-31. https://doi.org/10.1016/j.chb. 2009.07.007

Hong, J.-C., Tsai, C.-R., Hsiao, H.-S., Chen, P.-H., Chu, K.-C., Gu, J., \& Sitthiworachart, J. (2019). The effect of the "Predictionobservation-quiz-explanation" inquiry-based e-learning model on flow experience in green energy learning. Computers \& Education, 133, 127-138. https://doi.org/10.1016/j.compedu.2019.01.009

Hsieh, Y.-H., Lin, Y.-C., \& Hou, H.-T. (2016). Exploring the role of flow experience, learning performance and potential behavior clusters in elementary students' game-based learning. Interactive Learning Environments, 24(1), 178-193. https://doi.org/10.1080/10494820.2013.834827

Hsu, C.-L., \& Lu, H.-P. (2004). Why do people play on-line games? An extended TAM with social influences and flow experience. Information \& Management, 41(7), 853-868. https://doi.org/10.1016/j.im.2003.08.014

$\mathrm{Hu}$, L.-T., \& Bentler, P. M. (1998). Fit indices in covariance structure modeling: sensitivity to underparameterized model misspecification. Psychological Methods, 3(4), 424.

Hu, P.J.-H., \& Hui, W. (2012). Examining the role of learning engagement in technology-mediated learning and its effects on learning effectiveness and satisfaction. Decision Support Systems, 53(4), 782-792.

Khan, I. U., Hameed, Z., Yu, Y., \& Khan, S. U. (2017). Assessing the determinants of flow experience in the adoption of learning management systems: the moderating role of perceived institutional support. Behaviour \& Information Technology, 36(11), 1162-1176. https://doi.org/10.1080/0144929X.2017.1362475

Kock, N. (2015). Common method bias in PLS-SEM: a full collinearity assessment approach. International Journal of e-Collaboration (ijec), 11(4), 1-10.

Kothgassner, O. D., Goreis, A., Kafka, J. X., Hlavacs, H., Beutl, L., Kryspin-Exner, I., \& Felnhofer, A. (2018). Agency and gender influence older adults' presence-related experiences in an interactive virtual environment. Cyberpsychology, Behavior, and Social Networking, 21(5), 318-324.

Koufaris, M. (2002). Applying the technology acceptance model and flow theory to online consumer behavior. Information Systems Research, 13(2), 205-223.

Kwak, K. T., Choi, S. K., \& Lee, B. G. (2014). SNS flow, SNS self-disclosure and post hoc interpersonal relations change: focused on Korean Facebook user. Computers in Human Behavior, 31, 294-304. https://doi.org/10.1016/j.chb.2013. 10.046

Lee, M.-C. (2010). Explaining and predicting users' continuance intention toward e-learning: an extension of the expectation-confirmation model. Computers \& Education, 54(2), 506-516. https://doi.org/10.1016/j.compedu.2009.09.002

Limayem, M., \& Cheung, C. M. (2008). Understanding information systems continuance: the case of Internet-based learning technologies. Information \& Management, 45(4), 227-232.

Lin, M.-H., \& Chen, H.-G. (2017). A study of the effects of digital learning on learning motivation and learning outcome. Eurasia Journal of Mathematics, Science and Technology Education, 13(7), 3553-3564.

Liu, S.-H., Liao, H.-L., \& Pratt, J. A. (2009). Impact of media richness and flow on e-learning technology acceptance. Computers \& Education, 52(3), 599-607. https://doi.org/10.1016/j.compedu.2008.11.002

Liu, X., Bonk, C. J., Mclntyre, S., \& Magjuka, R. (2008). An investigation of the relationship between flow in computer-mediated interaction and virtual learning team effectiveness. Paper presented at the E-Learn: World Conference on E-Learning in Corporate, Government, Healthcare, and Higher Education

Lohmoller, J. B. (1989). Latent variable path modelling with partial least squares. Physica-verlag.

Lu, Y., Wang, B., \& Lu, Y. (2019). Understanding key drivers of mooc satisfaction and continuance intention to use. Journal of Electronic Commerce Research, 20(2)

MacKenzie, S. B., Podsakoff, P. M., \& Podsakoff, N. P. (2011). Construct measurement and validation procedures in MIS and behavioral research: integrating new and existing techniques. MIS Quarterly, 35(2), 293-334.

Mahnke, R., Benlian, A., \& Hess, T. (2014). Flow experience in information systems research: revisiting its conceptualization, conditions, and effects

Mahnken, A. H., Baumann, M., Meister, M., Schmitt, V., \& Fischer, M. R. (2011). Blended learning in radiology: Is self-determined learning really more effective? European Journal of Radiology, 78(3), 384-387. https://doi.org/10.1016/j.ejrad. 2010.12.059

Matute-Vallejo, J., \& Melero-Polo, I. (2019). Understanding online business simulation games: the role of flow experience, perceived enjoyment and personal innovativeness. Australasian Journal of Educational Technology, 35(3)

Meyer, K. A., \& Jones, S. J. (2013). Do students experience flow conditions online? Online Learning Journal, 17(3)

Monecke, A., \& Leisch, F. (2012). semPLS: structural equation modeling using partial least squares

Moon, J.-W., \& Kim, Y.-G. (2001). Extending the TAM for a world-wide-web context. Information \& Management, 38(4), $217-230$.

Muqtadiroh, F. A., Herdiyanti, A., Wicaksono, I., \& Usagawa, T. (2019). Analysis of factors affecting continuance intention of e-learning adoption in lecturers' perspectives. Paper presented at the IOP Conference Series: Materials Science and Engineering

Nakamura, J., Dwight, C., \& Shankland, S. (2019). The experience of intrinsic motivation. The Oxford Handbook of Human Motivation, 169

Novak, T. P., \& Hoffman, D. L. (1997). Measuring the flow experience among web users. Interval Research Corporation, 31(1), $1-35$.

Novak, T. P., Hoffman, D. L., \& Duhachek, A. (2003). The influence of goal-directed and experiential activities on online flow experiences. Journal of Consumer Psychology, 13(1-2), 3-16.

Novak, T. P., Hoffman, D. L., \& Yung, Y.-F. (2000). Measuring the customer experience in online environments: a structural modeling approach. Marketing Science, 19(1), 22-42. 
Oliveira, W. (2019). Towards automatic flow experience identification in educational systems: a human-computer interaction approach. Paper presented at the Extended Abstracts of the Annual Symposium on Computer-Human Interaction in Play Companion Extended Abstracts

Ortega-Arranz, A., Bote-Lorenzo, M. L., Asensio-Perez, J. I., Martinez-Mones, A., Gomez-Sanchez, E., \& Dimitriadis, Y. (2019). To reward and beyond: analyzing the effect of reward-based strategies in a MOOC. Computers \& Education, 142, 103639.

Podsakoff, P. M., MacKenzie, S. B., Lee, J.-Y., \& Podsakoff, N. P. (2003). Common method biases in behavioral research: a critical review of the literature and recommended remedies. Journal of Applied Psychology, 88(5), 879.

Rahmi, B., Birgoren, B., \& Aktepe, A. (2018). A meta analysis of factors affecting perceived usefulness and perceived ease of use in the adoption of e-learning systems. Turkish Online Journal of Distance Education, 19(4), 4-42.

Rasheed, R. A., Kamsin, A., \& Abdullah, N. A. (2020). Challenges in the online component of blended learning: a systematic review. Computers \& Education, 144, 103701. https://doi.org/10.1016/j.compedu.2019.103701

Ringle, W., Wende, S., Will, A. (2010). SmartPLS release: 2.0 M3: Supply Management, University of Hamburg. Retrieved from http://www.smartpls.de

Rodríguez-Ardura, l., \& Meseguer-Artola, A. (2016). What leads people to keep on e-learning? An empirical analysis of users' experiences and their effects on continuance intention. Interactive Learning Environments, 24(6), 1030-1053. https://doi.org/10.1080/10494820.2014.926275

Rodríguez-Ardura, I., \& Meseguer-Artola, A. (2017). Flow in e-learning: what drives it and why it matters. British Journal of Educational Technology, 48(4), 899-915.

Rodríquez-Ardura, I., \& Meseguer-Artola, A. (2019). Flow experiences in personalised e-learning environments and the role of gender and academic performance. Interactive Learning Environments. https://doi.org/10.1080/10494820. 2019.1572628

Rodríguez-Ardura, I., \& Meseguer-Artola, A. (2020). How to prevent, detect and control common method variance in electronic commerce research. Journal of Theoretical and Applied Electronic Commerce Research, 15(2), i-v.

Saadé, R., \& Bahli, B. (2005). The impact of cognitive absorption on perceived usefulness and perceived ease of use in on-line learning: an extension of the technology acceptance model. Information \& Management, 42(2), 317-327. https://doi.org/10.1016/j.im.2003.12.013

Sahid, D. S. S., Nugroho, L. E., \& Santosa, P. I. (2016). Modeling the flow experience for personalized context aware e-learning. Paper presented at the 2016 8th International Conference on Information Technology and Electrical Engineering (ICITEE)

Sanchez-Franco, M. J. (2010). WebCT—-the quasimoderating effect of perceived affective quality on an extending Technology Acceptance Model. Computers \& Education, 54(1), 37-46. https://doi.org/10.1016/j.compedu.2009.07.005

Sarstedt, M., Hair, J. F., Ringle, C. M., Thiele, K. O., \& Gudergan, S. P. (2016). Estimation issues with PLS and CBSEM: where the bias lies! Journal of Business Research, 69(10), 3998-4010. https://doi.org/10.1016/j.jbusres.2016.06.007

Sarstedt, M., \& Wilczynski, P. (2009). More for less? A comparison of single-item and multi-item measures. Die Betriebswirtschaft, 69(2), 211.

Scherer, R., \& Teo, T. (2019). Editorial to the special section-technology acceptance models: what we know and what we (still) do not know. British Journal of Educational Technology, 50(5), 2387-2393. https://doi.org/10.1111/bjet.12866

Schindler, L. A., Burkholder, G. J., Morad, O. A., \& Marsh, C. (2017). Computer-based technology and student engagement: a critical review of the literature. International Journal of Educational Technology in Higher Education, 14(1), 1-28.

Schophuizen, M., Kreijns, K., Stoyanov, S., \& Kalz, M. (2018). Eliciting the challenges and opportunities organizations face when delivering open online education: a group-concept mapping study. The Internet and Higher Education, 36, $1-12$.

Siekpe, J. S. (2005). An examination of the multidimensionality of flow construct in a computer-mediated environment. Journal of Electronic Commerce Research, 6(1), 31.

Song, S. H., \& Keller, J. M. (2001). Effectiveness of motivationally adaptive computer-assisted instruction on the dynamic aspects of motivation. Educational Technology Research and Development, 49(2), 5. https://doi.org/10.1007/BF025 04925

Soper, D. S. (2019). A-priori sample size calculator for multiple regression [Software]. Retrieved from http://www.danie Isoper.com/statcalc

Sosik, J. J., Kahai, S. S., \& Piovoso, M. J. (2009). Silver bullet or voodoo statistics? A primer for using the partial least squares data analytic technique in group and organization research. Group \& Organization Management, 34(1), 5-36.

Stavropoulos, V., Alexandraki, K., \& Motti-Stefanidi, F. (2013). Flow and telepresence contributing to internet abuse: differences according to gender and age. Computers in Human Behavior, 29(5), 1941-1948. https://doi.org/10.1016/j. chb.2013.03.011

ŠUmak, B., HeričKo, M., \& PušNik, M. (2011). A meta-analysis of e-learning technology acceptance: the role of user types and e-learning technology types. Computers in Human Behavior, 27(6), 2067-2077.

Sun, H., \& Zhang, P. (2006). The role of moderating factors in user technology acceptance. International Journal of HumanComputer Studies, 64(2), 53-78.

van den Hout, J. J., \& Davis, O. C. (2019). The individual flow experience in the context of teams. In Team Flow (pp. 7-24): Springer

Wang, L. C., Baker, J., Wagner, J. A., \& Wakefield, K. (2007). Can a retail web site be social? Journal of Marketing, $71(3)$, 143-157. https://doi.org/10.1509/jmkg.71.3.143

Wang, S., Wang, T., Chen, N., \& Luo, J. (2020). The preconditions and event-related potentials correlates of flow experience in an educational context. Learning and Motivation, 72, 101678. https://doi.org/10.1016/j.lmot.2020.101678

Watted, A., \& Barak, M. (2018). Motivating factors of MOOC completers: comparing between university-affiliated students and general participants. The Internet and Higher Education, 37, 11-20. https://doi.org/10.1016/j.iheduc.2017.12.001

Weibel, D., \& Wissmath, B. (2011). Immersion in computer games: the role of spatial presence and flow. International Journal of Computer Games Technology. https://doi.org/10.1155/2011/282345 
Zainuddin, Z., Shujahat, M., Haruna, H., \& Chu, S. K. W. (2020). The role of gamified e-quizzes on student learning and engagement: an interactive gamification solution for a formative assessment system. Computers \& Education, 145, 103729. https://doi.org/10.1016/j.compedu.2019.103729

Zanjani, N. (2015). Success factors of engaging higher education students and staff with e-learning tools within Learning Management Systems. (Doctoral dissertation, Queensland University of Technology). Retrieved from https://eprin ts.qut.edu.au/83940/

Zhao, Y., Wang, A., \& Sun, Y. (2020). Technological environment, virtual experience, and MOOC continuance: a stimulusorganism-response perspective. Computers \& Education, 144, 103721. https://doi.org/10.1016/j.compedu.2019. 103721

Zimanyi, Z., \& Schüler, J. (2021). The dark side of the moon. In C. Peifer \& S. Engeser (Eds.), Advances in flow research (pp. 171-190). Springer International Publishing.

\section{Publisher's Note}

Springer Nature remains neutral with regard to jurisdictional claims in published maps and institutional affiliations.

\section{Submit your manuscript to a SpringerOpen ${ }^{\circ}$} journal and benefit from:

- Convenient online submission

- Rigorous peer review

- Open access: articles freely available online

- High visibility within the field

- Retaining the copyright to your article

Submit your next manuscript at $\gg$ springeropen.com 